\title{
Validity of Learning Tools with Peer Tutor Model in Improving Student Learning Outcomes and Self Efficacy
}

Elly Yustina*, Suryajaya, Supramono

Masters Program of Natural Sciences Teaching, Lambung Mangkurat University, Banjarmasin, Indonesia

\begin{tabular}{l|l}
\hline DOI: $10.36348 /$ jaep.2020.v04i03.003 & | Received: 06.03 .2020 | Accepted: $13.03 .2020 \mid$ Published: 21.03 .2020 \\
*Corresponding author: Elly Yustina &
\end{tabular}

Abstract

This study aims to determine the validity of learning tools with peer tutoring models in improving student learning outcomes and Self Efficacy on Newton's Law material. The development model used is the ASSURE model, but only to stage 5 (Requires Learner Participation). Test the product in step 5 using Tessmer. The validation data subjects were 3 expert validators, while the practical data subjects were 2 partner teachers, and the effectiveness data subjects were grade VIII students of SMPN 10 Banjarbaru. The type of data collected is validity data. Validity data collection techniques are carried out through the validation of learning tools developed using the validation sheet instrument. Data analysis was performed using descriptive techniques. The results showed that, the developed learning tool has a very valid category. This result is supported by the opinions of 3 students in individual trial activities (one to one). Based on the results of development and research shows that the learning tools developed are valid, practical and effective.

Keywords: Peer tutors, learning outcomes, self efficacy, assure, learning tools.

Copyright @ 2020: This is an open-access article distributed under the terms of the Creative Commons Attribution license which permits unrestricted use, distribution, and reproduction in any medium for non-commercial use (NonCommercial, or CC-BY-NC) provided the original author and sources are credited.

\section{INTRODUCTION}

The success of a learning activity can be seen from the results of learning and self-efficacy that are formed in students, learning activities are said to be successful if students can achieve the criteria of SKL (standard competency of graduates). In the explanation of Article 35 of Law Number 20 Year 2003 it is stated that the graduate competency standard (SKL) is a qualification of the ability of graduates which includes the attitudes, knowledge, and skills of students that must be fulfilled or achieved from an educational unit at the level of primary and secondary education. Based on the graduation data of junior high school students in the Banjarbaru municipal schools in the 2015 National Exam (UN) through 2017, the average UN score for natural science subjects over the past three years has not been satisfactory. In 2015 to 2016 there was a decline in the average UN score in 7 schools out of 14 existing schools, but in 2016 to 2017 the situation was precisely all state junior high schools experienced a decline in the UN average, in fact only 2 schools could achieve grades above 55, namely SMPN 1 Banjarbaru and SMPN 2 Banjarbaru.

There are indications of low self efficacy in students. This indication is shown by their attitude when answering questions on the National Examination
(UN). Even though the previous answer is correct, but because of the lack of confidence (efficacy) of students, then they delete it and replace it with other answer choices, and it turns out to be wrong. Self efficacy influences learning outcomes[1]. Confidence (efficacy) is the main basis of an action. The results of the 2015 PISA study, showed an average score of self-efficacy literacy of students in Indonesia was 403. These results put Indonesia ranked ninth from the bottom, which ranks 62 out of 70 participating countries[2, 3]. The self efficacy literacy score and average score do not differ greatly from the results of the previous PISA test and survey in 2012 which showed a score of 375 , placing Indonesia at number 64 out of 65 countries[2]. From these results, it shows that the self efficacy of students in Indonesia is still relatively low.

The low quality of learning outcomes and selfefficacy of students is influenced by various aspects both directly and indirectly related to the learning process of students at school[4]. These aspects include; learning tools that are used are not sufficient to improve learning outcomes and students' self-efficacy, the approach used also does not involve students. The approach that most educators use is lectures, learning like this causes the learning process that occurs is only the transfer of knowledge without involving students in 
the process of understanding a science. Transfer of knowledge alone without involving students is what causes the results/output of students in Indonesia far behind compared to other countries [5]. In addition, the methods/strategies used only make students as objects, not learning subjects. This is thought to be the cause of the low quality of student learning outcomes and the difficulty of building self-efficacy in students.

Based on the description above, the researcher concludes that it is necessary to develop learning tools oriented towards a learning model that can solve students' learning problems, as well as provide opportunities for students to actively build their own aspects of knowledge, attitudes and skills. Such learning is very important to be realized in the classroom, because learning is active mental work, not passively accepting teaching from educators. In this process educators play an important role by providing support, thinking challenges, serving as a trainer, but students remain the key to learning [6].

Although there are many learning tools
available from various sources (such as experts/developers from the central government, local government, and private parties) as a reference for educators. However, with the progress of education demands so rapidly today educators are still required to be able to develop and implement an ideal learning tool by considering things such as the characteristics of the subject matter to be taught, personal characteristics of students who study it, geographical conditions, and social- the culture of the local area while still paying attention to the guidelines mandated in the curriculum.

Based on aspects of the causes of low learning outcomes and self-efficacy that occur in students, the learning of science will be more optimal if learning moves from being teacher-centered to student-centered or the role of educators who are only as conveyers of learning material (transformer) switches to the role of facilitator. There are many models that can be used in the learning process in the classroom by involving the active role of students, one of which is the Peer Tutor model. The use of Peer Tutor learning models is more effective compared to learning that uses conventional learning models in terms of improving aspects of attitudes and student learning outcomes [7]. Through Peer Tutors, students are not only involved in learning, but peer tutors can also provide solutions / assistance to their peers in learning difficulties. The above opinion is corroborated by the results of students' character analysis by the researcher. Where $100 \%$ correspondents answered more often to classmates who he thought were smart to help his difficulties in learning.

In the same questionnaire, $100 \%$ of the correspondents answered questions about science materials that were difficult to learn during class VII were those related to the laws and formulas and the application of formulas in the matter of calculation. One of the natural science materials related to laws and formulas is Newton's Law material. There are three laws that must be understood by students in studying Newton's Law, namely Newton's First Law, Newton's Second Law and Newton's Third Law, and linking these laws with the reality encountered in everyday life. An understanding of formulas and their application in matter of counts is contained in Newton's Law II sub material. To make it easier for students to understand this material, the teacher can use the Peer Tutor learning model.

\section{RESEARCH METHODS}

This type of research is classified into development research. Called development research because in this study the development of learning tools was carried out including syllabus, lesson plans, teaching materials, LKPD and assessment sheets (LP). Development of learning tools refers to the ASSURE model. The research procedure begins with the Student Character Analysis (Analyze Learners), then continues with the Determination of Learning Objectives (State Objectives). The next step is Choosing Methods, Media and Teaching Materials (Select Methods, Media, and Materials) and Using material (Ultilize Material). Finally, it involves the participation of students (Requires Learner Participation). The study ends until the results of only formative evaluation (stage 5) are obtained. The Sumative Evaluation at stage 6 of ASSURE was not carried out due to the limitations of researchers in terms of time, energy and cost. The steps to formative evaluation results from this study are in line with the layers of formative evaluation in Tessmer. So to obtain the results of formative evaluation, researchers use the stages of formative evaluation according to Tessmer. Data collection techniques through one type, namely validity. The total number of students who became the study sample were 63 students.

\section{RESEARCH RESULTS AND DISCUSSION \\ Learning Tools Validation Results}

Validated learning tools include syllabus, lesson plans, LKPD, teaching materials, and assessment sheets obtained from the opinions of three experts/experts (Expert review). 
Elly Yustina et al; J Adv Educ Philos, March 2020; 4(3): 90-94

Table-1: A summary of the results of the syllabus validation by three experts is presented in the following

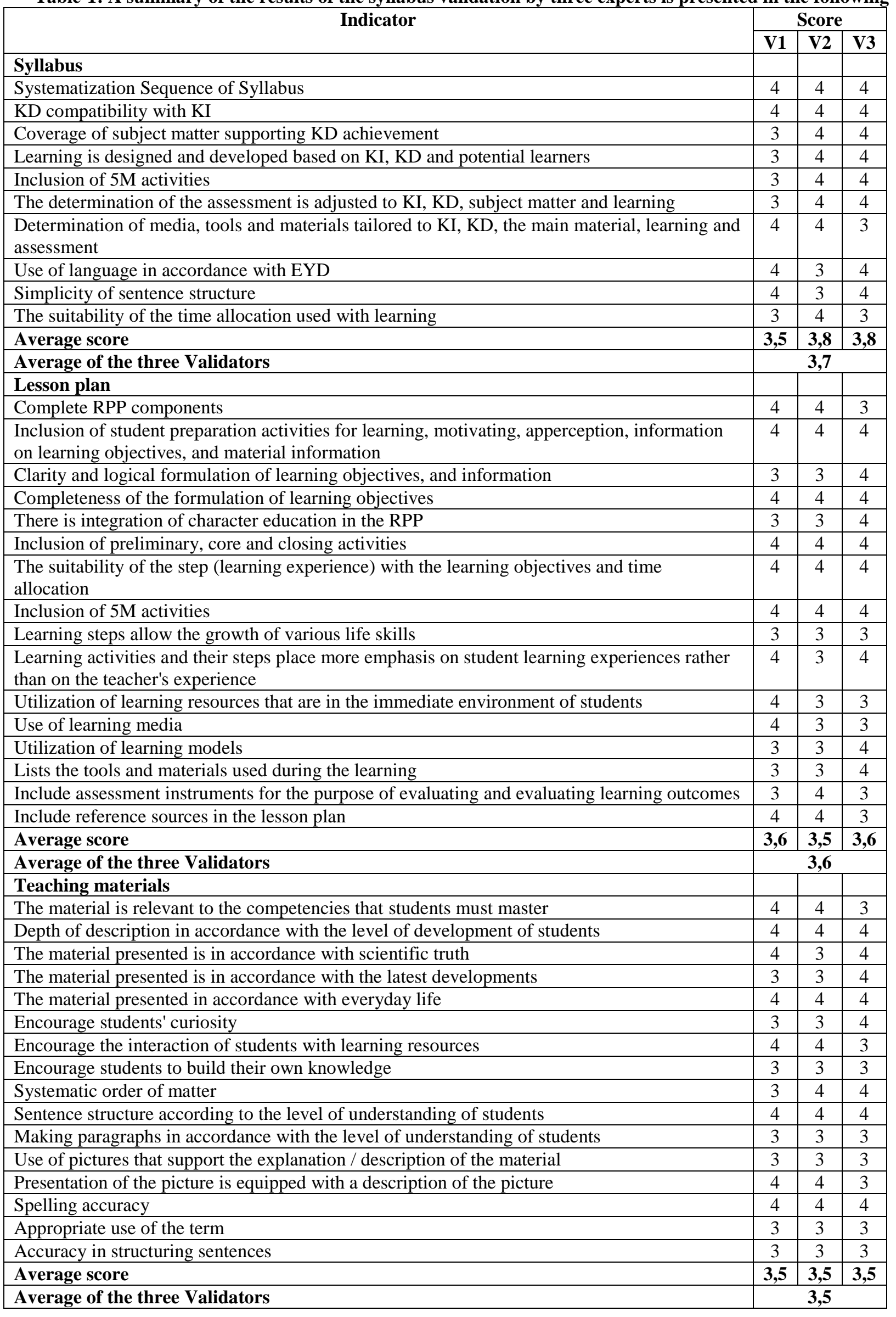


Elly Yustina et al; J Adv Educ Philos, March 2020; 4(3): 90-94

\begin{tabular}{|c|c|c|c|}
\hline \multicolumn{4}{|l|}{ LKPD } \\
\hline Give emphasis to aspects of the process of finding concepts & 3 & 3 & 3 \\
\hline The accuracy of the cases presented & 4 & 3 & 4 \\
\hline Systematic sequence & 3 & 4 & 3 \\
\hline The use of images that are interesting and support the material presented & 3 & 4 & 4 \\
\hline Use of language in accordance with EYD & 4 & 4 & 4 \\
\hline Simplicity of sentence structure & 4 & 4 & 4 \\
\hline The appearance of LKPD is interesting & 3 & 3 & 3 \\
\hline LKPD efficiency in relation to time & 4 & 3 & 4 \\
\hline LKPD efficiency in relation to costs & 4 & 3 & 4 \\
\hline LKPD efficiency in relation to personnel & 3 & 3 & 3 \\
\hline Average score & $\mathbf{3 , 5}$ & 3,4 & $\mathbf{3 , 6}$ \\
\hline Average of the three Validators & \multicolumn{3}{|c|}{3,5} \\
\hline \multicolumn{4}{|l|}{ Spiritual Assessment Instrument } \\
\hline The instructions for filling in the spiritual score are given in a clear and straightforward way & 3 & 3 & 3 \\
\hline Task Details Performance is continuous and clear & 4 & 4 & 4 \\
\hline Use of language in accordance with EYD & 4 & 4 & 4 \\
\hline Simplicity of sentence structure in the details of the Performance Task & 3 & 3 & 3 \\
\hline Average score & $\mathbf{3 , 5}$ & 3,5 & 3,5 \\
\hline Average of the three Validators & \multicolumn{3}{|c|}{3,5} \\
\hline \multicolumn{4}{|l|}{ Character Rating Instrument } \\
\hline Instructions for filling in the character score scores are given in a clear and concise manner & 3 & 3 & 3 \\
\hline Task Details Performance is continuous and clear & 4 & 4 & 4 \\
\hline Use of language in accordance with EYD & 4 & 4 & 4 \\
\hline Simplicity of sentence structure in the details of the Performance Task & 3 & 4 & 3 \\
\hline Average score & $\mathbf{3 , 5}$ & 3,7 & $\mathbf{3 , 5}$ \\
\hline Average of the three Validators & \multicolumn{3}{|c|}{3,6} \\
\hline \multicolumn{4}{|l|}{ Cognitive Assessment Instrument } \\
\hline Instructions in answering questions are given in a concise and clear manner & 3 & 3 & 3 \\
\hline Each item corresponds to the learning objectives & 4 & 4 & 4 \\
\hline Use of language in accordance with EYD & 3 & 3 & 3 \\
\hline Simplicity of sentence structure & 4 & 4 & 4 \\
\hline Average score & $\mathbf{3 , 5}$ & 3,5 & 3,5 \\
\hline Average of the three Validators & \multicolumn{3}{|c|}{3,5} \\
\hline \multicolumn{4}{|l|}{ Psychomotor Assessment Instrument } \\
\hline Instructions for filling in the Psychomotor assessment score are given in clear terms & 3 & 3 & 3 \\
\hline Task Details Performance is continuous and clear & 3 & 3 & 3 \\
\hline Use of language in accordance with EYD & 4 & 4 & 4 \\
\hline Simplicity of sentence structure in the details of the Performance Task & 4 & 4 & 4 \\
\hline Average score & $\mathbf{3 , 5}$ & 3,5 & 3,5 \\
\hline Average of the three Validators & & 3,5 & \\
\hline
\end{tabular}

\section{Discussion of the Validity of Learning Devices}

The RPP tools are valid based on 1) syllabus assessment, 2) RPP, 3) teaching materials, 4) LKPD, 5) assessment sheets. This research has resulted in a prototype of a valid, practical and effective RPP tool. Nieveen [8] in Mafumiko [9] explains the prototype means all products that are designed before getting the final product or duplicated and fully implemented in real conditions.

The lesson plan is valid based on syllabus indicators, lesson plans, LKPD, teaching materials and assessment sheets. The device is said to be valid if the assessment of all aspects validated has a good category [10]. A valid Learning Implementation Plan Tool if the components are in accordance with the validity indicators of the lesson plan [11]. Validation is one of the criteria that determine the quality of a product [12].

Students as users think that LKPD, teaching materials and evaluation tools are good and students' opinions are at least good categories [13]. Individual test (one-to-one) aims to identify grammatical errors, spelling, punctuation, unclear instructions, incorrect capitals, and missing graphics [14]. Individual tests complete evaluation information from the learner's point of view.

\section{CONCLUSION}

The results of research conducted in general are able to answer the research objectives. The purpose of this study is to improve student learning outcomes 
and self-efficacy through the development of learning tools with Peer Tutor models in Newton's Law material that are valid, practical, and effective. The results of the development and research showed that the learning tools developed were considered appropriate for use.

Validity is done using the level of validation of experts (experts and practitioners) represented by two lecturers and one teacher. Based on the results of the validation data, the instruments including syllabus, lesson plans, teaching materials, LKPD, and LP LKPD meet the validity requirements (valid and very valid) based on the results of expert validation.

\section{REFERENCES}

1. Schunk, D. H., \& Meece, J. L. (2005). Self Efficacy Development in Adolescences. In F. Pajares, \& T. C. Urdan, Self Efficacy Beliefs of Adolescencents. Greenwich: Information Age Publishing,71-96.

2. OECD. (2013). Education at a Glance 2013: OECD Indicators. OECD Publishing. doi:http://dx.doi.org/10.1787/eag-2013-en

3. OECD. (2016). Education at a Glance 2013: OECD Indicators. OECD Publishing. doi:https://doi.org/10.1787/19991487

4. Astina, Y. (2016). Pengembangan Perangkat Pembelajaran Konsep Sistem Organisasi Kehidupan Dengan Model Kooperatif Tipe Group Investigation (GI) Terhadap Peningkatan Keterampilan Proses dan Self Efficacy Peserta Didik. Thesis, Universitas Lambung Mangkurat, Magister Keguruan IPA, Banjarmasin.

5. Saktyowati, D. O. (2011). Panduan Pendidik: Meningkatkan Mutu Pendidikan Dalam Pembelajaran Sains. Jakarta: CV. Ghina Walafafa.
6. Nur, M. (2001). Pembelajaran Kooperatif Dalam Kelas IPA. Surabaya: Universitas Negeri Surabaya.

7. Herianto, D. (2010). Efektivitas Model Pembelajaran Tutor Sebaya Terhadap Hasil Belajar Siswa Kelas VIII SMPN 2 Mei Banjaran. Bandung: Universitas Pendidikan Indonesia.

8. Nieveen, N. (1999). Prototyping to Reach Product Quality. In J. v. Akker, R. Branch, K. Gustafson, N. Nieveen, \& P. T, Design Aproaches and Tools in Education and Training. Dordrecht: Kluwer Academic Publishers.

9. Mafumiko, F. (2006). Micro-Scale Experimentation as a Catalyst for Improving The Chemistry Curriculum in Tanzania. Twente: University of Twente-Enschede.

10. Nisa, I. (2012). Pengembangan Perangkat RPP IPA Terpadu Tipe Connected dengan Topik Peredaran Darah untuk Kelas VIII SMP. Jurnal Pendidikan Sains, 1(1), 26-38.

11. Dewi, K., Sadia, W. I., \& Ristiati, P. N. (2013). Pengembangan Perangkat RPP IPA Terpadu dengan Setting Inkuiri Terbimbing untuk Meningkatkan Pemahaman Konsep dan Kinerja Ilmiah Siswa. Jurnal Pascasarjana Universitas Pendidikan Ganesha Program studi IPA.

12. Akker, J. V., Bannan, B., Anthony, E., Kelly, Nieveen, N., \& Plomp, T. (2007). An Introduction to Education Design Research. Proceedings of The Seminar Conducted at The East China Normal University. Shanghai.

13. Riduwan. (2015). Skala Pengukuran Variabelvariabel Penelitian. Bandung: Alfa beta.

14. Tessmer, M. (1993). Planning and Conducting Formative Evaluations. London: Kogen Page. 